\title{
ROLE OF DEFENCE FORCES OF SRI LANKA DURING THE COVID-19 OUTBREAK FOR NATIONS BRANDING
}

\author{
Thesara V.P. Jayawardane $\square$ \\ Department of Industrial Management \\ University of Moratuwa, Moratuwa, Sri Lanka.
}

\begin{abstract}
World Health Organization (WHO) confirmed of a novel coronavirus on the 12th January 2020, as the cause of a respiratory illness in a cluster of people in Wuhan City, China. Even though the fatality ratio for coronavirus disease 2019 (COVID-19) is comparatively lower than SARS, the transmission is greater. Therefore, Sri Lankan government requested the general public to practice proper hygiene methods and selfquarantine methods to safeguard from this disease. Quarantine Law in Sri Lanka is governed by the Quarantine and Prevention of Disease Ordinance No 3 of 1897. Defence Forces of Sri Lanka played many roles in the fight against COVID-19 and this research is an overview of the contribution they have made towards battling the COVID-19 successfully. The purpose of this research is to identify the effectiveness of the measures taken by the Sri Lankan government and the tri forces to stop COVID-19 spreading, which will provide an example for other countries to follow on how to prepare, detect, and respond to similar outbreaks, which in turn will contribute towards Nations Branding. This research is a qualitative study mainly undertaken with content analysis of the information extracted from secondary data such as publications of the local and foreign governments, research reports from Centres for Disease Control and Prevention (CDC) and World Health Organization (WHO), magazines, newspapers, TV programmes and websites. A few face-to-face and telephone conversations were also conducted with key personnel of the defence forces to obtain an in depth understanding and to clarify the accuracy of the results. The key contributions made by Sri Lanka Army (Army), Sri Lanka Navy (Navy) and Sri Lanka Air Force (SLAF) were identified in terms of its implications for Nations Branding and, recommendations are made which includes methods to adopt when dealing with COVID 19 in the future.
\end{abstract}

Keywords: Defence Forces, Coronavirus Disease, COVID-19, Sri Lanka, Nations Branding

\section{Background}

COVID-19 has caused a worldwide pandemic due to severe acute respiratory syndrome. Sri Lanka reported its' first confirmed patient due to this disease on 27 January 2020, when a 44-year-old Chinese woman from Hubei, China was admitted to the National Institute of Infection Diseases (IDH). A total of over 23,000 confirmed cases have been reported in Sri Lanka by 01 December 2020, with 122 deaths. Army built forty-five Quarantine Centre (QC) s in Sri Lanka by 23 of March as a defensive measure to attack the coronavirus. In these $45 \mathrm{QCs}$, thousands of people were occupied time to time with over 50 foreigners from 14 different countries. Sri Lanka news media (Newsfirst 16 April 2020) reported that "Sri Lanka has been named as 16th high risk country prone to virus pandemic" and (Newsfirst 17 April 2020) reported that "Sri Lanka has been ranked 9th best country in the world for its successful immediate response on tackling the virus". Nation branding is concerned with a country's whole image on the international stage, covering political, 
economic, and cultural dimensions (Anholt 2007) thus, the positive image obtained from the rapid actions taken during the pandemic certainly brought fame and recognition to the nation internationally.

Sri Lankan President directed the authorities to implement proper QCs to examine the foreigners and ordered relevant authorities to provide necessary essential services to the general public via internet (Daily News, 20 March 2020). Soon, the government issued a circular stating that the special task force has been established to effectively and efficiently regulate and conduct the mechanism of distribution of essential commodities among public (Daily News, 24 March 2020).

On the 7 April 2020, Army 1 Corps of Engineer Services (CES) made the Voice of America building complex, Iranawila, Chilaw in to an isolation hospital. This hospital was provided with robotic technology along with autopilot vehicles to be used by the medical staff working there as a safety measure. COVID-19 patients were confined to isolated areas where robots transported medicine, food and drinks through this special airlock system.

After two months of island wide curfew, on the 11 May 2020, Sri Lankan government ended the 52-day lockdown style curfew. This allowed people to return to workplace while maintaining social distancing but the public gatherings and celebrations were not allowed. 5 August 2020 was a significant day for Sri Lanka where the 2020 Sri Lankan parliamentary election was held in spite of COVID-19 with a voter turnout of nearly $75 \%$. Wearing face masks and using hand sanitizers were made compulsory at the polling stations and social distancing was maintained throughout. Sri Lanka's Health Ministry has geographically earmarked 'Medical Officer of Health' areas across the island of 21 million, to provide preventive health services at a community level, through a team of medical officers, public health nurses, health inspectors and midwives.

\section{Research Problem}

COVID-19 has been challenging the world in many unexpected ways, and people need to adjust their lifestyles accordingly in order to move on to the future with the pandemic. Throughout the pandemic and currently as of now, Tri Force members of the Defence Forces of Sri Lanka are working tirelessly to halt the spread of COVID-19 that has affected over 23,000 people and claimed over 100 lives (Health Promotion Bureau, 2020). In this global pandemic situation, with its immeasurable burden of deaths and scope of devastation, and no vaccine in sight there is a perfect public diplomatic space for nation branding as "a strategic, policy-making approach, designed to help places build on the strengths that will earn them a better reputation" (Anholt 2007).

A systematic and impartial assessment that provides credible and reliable evidencebased information about the extent to which this contribution was made by the Defence forces has not been carried out. By identifying their priceless effort, we not only can pay due credit and respect, but the findings will contribute towards recognising the important role a country's tri forces can play when facing a pandemic or a similar disease situation. It will provide guidance for the future for Sri Lanka or for any other country which may encounter such conditions.

"The history-as-lessons can be learnt on the assumption that epidemics are structurally comparable events, wherever and whenever they take place. The COVID-19 outbreak creates a sense similarity with the SARS and MERS" (Li, 2020). Elder (2010) emphasised how military service was able to serve as a positive turning point, providing valued resources as well as new reference and support groups in times of a crisis including a pandemic. "Bruce Aylward, a senior adviser to WHO's Director-General who coled the WHO-China Joint Mission on COVID-19 in late February, 2020, praised China's efforts as probably the most ambitious, agile and aggressive disease containment effort in history" (Zhong, 2020).

Studies have been conducted on the efforts against COVID-19 by many countries in the world but the contribution of the Sri Lankan government, especially the support extended by the Defence forces has not been studied in 
depth. The role of the Sri Lankan Defence forces in crisis management needs extensive research and in depth study which is why the author realised there is a research gap that needs to be filled. The research will also contribute to filling the gap in identifying how the efforts of the Defence forces in this crisis contributed in uplifting the Nations image and reputation.

Therefore, this research was conducted to fulfil the following objectives.

\section{Objectives}

1. To analyse the effects created by COVID-19 on Sri Lanka.

2. To identify the key contributions made by the Defence Forces of Sri Lanka during the battle against COVID-19 pandemic attack and its implications for Nations Branding.

3. To provide a guidance for Sri Lankans with ways to continue life amidst COVID-19.

\section{Literature Review}

Nation Branding is defined by Kerr (2013) as "the application of corporate marketing concepts and techniques to countries, in the interests of enhancing their reputation in international relations". Fan (2010) notes that, "as an emerging area of interest, nation branding is driven largely by practitioners and there is an urgent need for conceptual and theoretical development of the subject". Even during the crisis of COVID-19, the presumption that countries have their unique nation brand is not far-fetched at all. While many countries were associated with poor containment measures, insufficient test kits, or high death rates, Sri Lanka boasts of a success story.

National Operation Center for Prevention of COVID- 19 Outbreak (NOCPCO) was initiated by the President HE Gotabaya Rajapaksa and, the Army Commander Shavendra Silva was appointed as the head of this centre. This can be seen as the initial instance where the military was officially roped into Sri Lanka's COVID-19 scenario. Sri Lanka Police (SLP) and Army joined hands to track down those reportedly in hiding, and evading quarantine. The Sunday Times newspaper (15 March 2020) reported that the "State Intelligence Service headed by a former military intelligence chief is leading the contact-tracing effort that involves perusal of immigration records and data analysis". The (former Acting) Inspector General of Police had to request the Criminal Investigation Department to take strict action against people who circulate malicious and false information about public servants involved in essential services.

The Defence Ministry and the Health Ministry joined hands and took all necessary precautions to prevent spreading of COVID 19 through travellers who are arriving from COVID-19 infected- countries among the 20 million of country's population. The first quarantine facility was set up in the Diyatalawa military hospital. Poonani and Kandakadu that function under the Army were declared as QCs to keep who are arriving from COVID 19 infected-countries for 14-days. Military Spokesman Brig. Chandana Wickramasinghe stated that "the government had decided to put those, who were coming from countries listed as 'risky' areas of COVID-19, under the quarantine process at two centres in the Eastern province as they are less populated areas and ideal to isolate them for a period of 14-days". He also added that "Those who are arriving in the country, whether they are infected or not, they have a right to return to their motherland. But they also need to be responsible, to protect those who are living in the country, by willingly undergoing the quarantine process to clear them to endorse that they are free of any viruses" (Defence.lk, March 2020).

Defence Secretary Gen. (Retd) Kamal Gunaratne confidently stated that the SL government will ensure the protection of country's 21.4 million people from COVID19. He reiterated that the Defence Ministry was working closely with the Health Ministry and other relevant authorities to provide assistance in the battle against COVID-19. (Defence.lk, 19 March 2020). He ensured that the Government would not let COVID-19 to spread throughout the country and that panic buying of essential items is not required. He spoke of the 
passengers COVID-19 infected-countries and stated that it was mandatory for them to undergo quarantine procedures for the safety of the country's entire population. He further explained that "the military, which was the first respondents in a disaster situation, had come forward to support to mitigate spreading the virus further. The military is also tasked to analyse past records, items used, places that the infected people had visited and people whom they had associated (Defence.lk, March 2020).

He further stated that "when a suspected coronavirus infected individual is identified, we direct them to a hospital such as the IDH and take all necessary measures to provide medical treatment. Taking precautionary measures will not end after admitting the patient to the hospital as we will find those who associated with the patients and, if we fail to trace their whereabouts, we will get the assistance of the intelligence agencies to track them to put them on self-quarantine process in their own houses" (Defence.lk, 14.03.20).

Defence Secretary Gen. (Retd) Kamal Gunaratne stated that "From manning roadblocks, erecting quarantine facilities to tracking and tracing potential coronavirus infected patients and from mass disinfection initiatives to distributing household goods and provisions to needy communities in the country, Army displayed capabilities. The intelligence agencies are providing exceptional results by promptly tracking and tracing individuals evading quarantine and identifying potential coronavirus carriers, who have associated with confirmed patients" (Defence.lk, 17 April 2020)

As Head of the NOCPCO, Chief of Defence Staff and Commander of the Army, General Shavendra Silva stated in a TV interview that throughout the COVID-19 battle, visionary and guiding support was continuously extended by the President, Prime Minister and the government. He fondly reiterated the contribution of the Health Minister, Director General of Health Services and Medical Specialists. He also discussed the Army's strategic interaction with other stakeholders, quick operational aspects with new innovations, use and coordination of intelligence, adaptability of security force personnel for civil coordination work and communicative strategies ('Big Focus' Derana TV, 29 July 2020).

'Nothing is Impossible,' is a motto constantly phrased by General Shavendra Silva who stated that "Sri Lanka being a small nation maintains the Armed Forces through the tax-payers' money and therefore we need to protect this nation from whatever the national emergency it is faced with, not only in times of security alone as we have repeatedly proved". He further discussed the importance of way forward strategy 20202025 and explained the process of transforming the Army to be a "professionally-competent and fully-pledged organization which can deal with any eventualities in future". $\mathrm{He}$ confidently pointed out that the President and the tri forces together would work towards a new era of development for Sri Lanka ('Big Focus' Derana TV, 29 July 2020).

Defence Secretary Gen. (Retd) Kamal Gunaratne mentioned that around the world, Sri Lanka is identified as the nation that deployed the intelligence service successfully to mitigate the spread of COVID-19. He added that at a time when all the developed countries face COVID-19 helplessly, Sri Lanka was facing it fearlessly as the government was well geared to mitigate the spread of the virus. He further stated that "Sri Lanka can be a role model for other countries on how the deadly virus could be curbed effectively. The entire credit should go to the country's leadership President Gotabaya Rajapaksa- who had drawn a comprehensive mechanism to face the challenge far ahead the virus reached us" (Defence.lk, 31 July 2020)

\section{Conceptual Framework}

“A conceptual framework is the researcher's idea on how the research problem will have to be explored" (Afibary, 2015). The conceptual framework guides the researcher in the specific direction by which the study will have to be undertaken. The conceptual framework will specify the variables that will have to be explored in the investigation. In order to come up with a conceptual 
framework which will guide this research, the literature was studied and the information obtained so far in previous studies were identified. A gap in terms of knowledge in the area of COVID-19 and the contribution made by the defence forces was identified.
Specific questions which need to be answered and problems that need to be given solutions were also selected. As a result, the researcher created a conceptual framework to serve as a guide in this research.

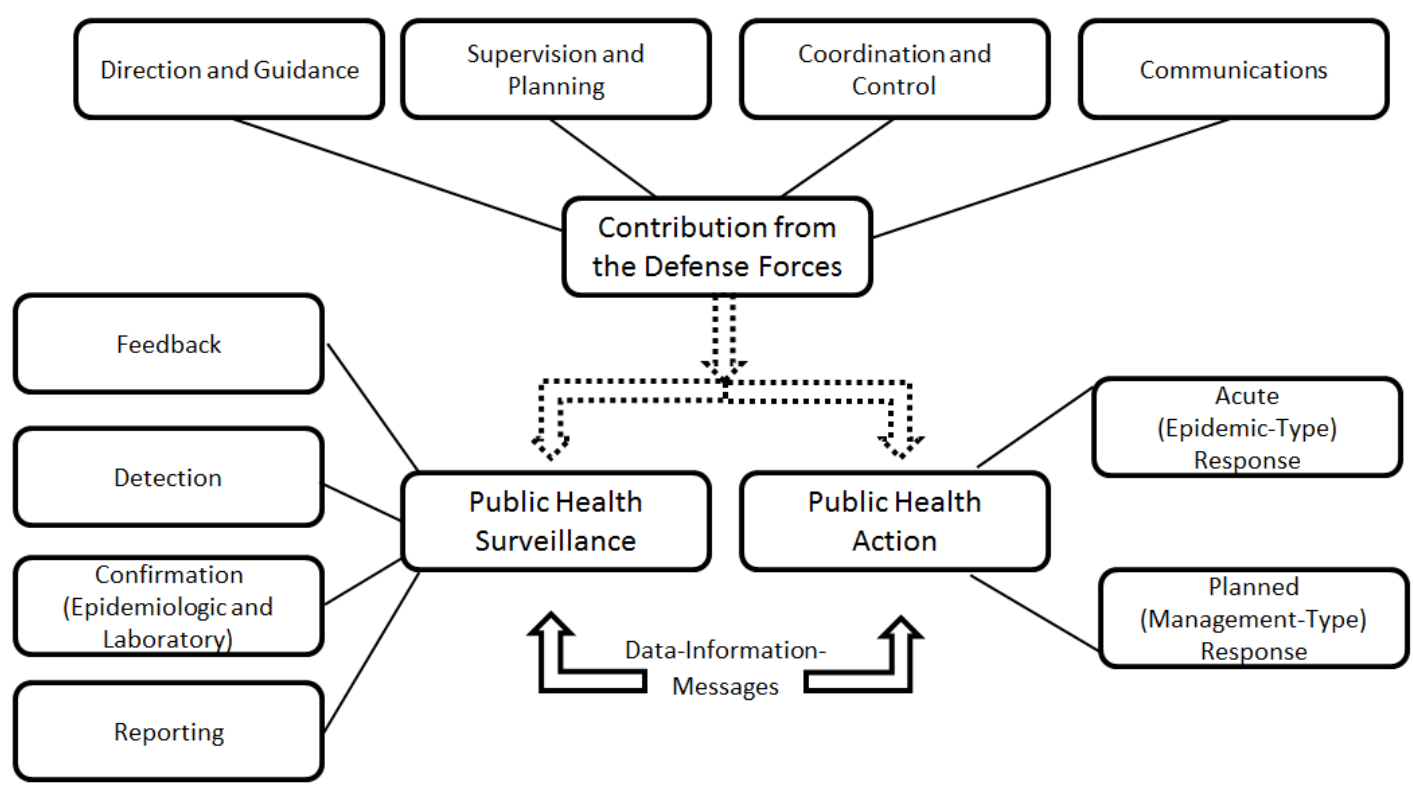

Figure 1: Conceptual Framework (Author Created)

With the aid of the above conceptual framework, the contributions made by the Defence Forces in the battle against COVID19 can be identified.

This frame work shall emphasise the fact that the Contribution from the Defence forces acts as a Moderating variable that affects the direction and strength of the relation between Public Health Surveillance and Public Health Action. When the contribution from the defence forces is strong and constant, that results in a strong Health system and when the contribution in minimal or poor, the result is negative on the health system. Nation branding is action-oriented; a country will have a hard time persuading others if its nation brand is without substance (Thompson 2020). Thus, with the strong support extended by the Defence forces in controlling the Covid-19, Sri Lanka could leverage on its existing strengths for nation branding.

As a theoretical implication leadership characteristic demonstrated by the defence forces can be recognised. The transformational leadership theory attracts many discussions and it is applicable on every sector including in the military (Bradley \& Charbonneau, 2004). The transformational leaders, especially in the military change their subordinates to the better making them accomplishing the missions ahead of time. When applied to this conceptual framework, transformational leadership can be seen as how the commanding officers inspire, motivate, influence and simulate the subordinates to the extent of building an extraordinary trust and believe between the two towards the common goal (Warilow, 2012) of the best interest of the country's health and security.

\section{Methodology}

This research is a narrative review of the literature where the response and contribution made by the Sri Lankan Government and Defence forces during the COVID-19 outbreak is analysed using various databases. Epidemic preparedness and Sri Lanka's response capacity, case identification and surveillance, healthcare facilities, and medical team preparation according to CDC and WHO frameworks, regulations, and guidelines were identified. 
Therefore, the methodology used for the purpose of this research study primarily involved with information obtaining from secondary data which was extracted and analysed in order to increase the validity and credibility of the findings. A number of faceto-face discussions and telephone conversations were conducted with selected personnel with superior authority in the defence forces in order to ensure the secondary data obtained is accurate and credible.

A lot of secondary data are being collected and archived by researchers all over the world for research that are becoming more widespread (Andrews et al. 2012). The major advantages of analysis of secondary data are the cost effectiveness and convenience it provides. When good secondary data are available, researchers can utilize them for high quality empirical researches. These provide researchers with opportunities to work effectively to test new ideas, theories, frameworks, and models of research design (Smith 2008).

Secondary data refers to data that is collected by someone other than the user. Common sources of secondary data for social science include censuses, information collected by government departments, organizational records and data that was originally collected for other research purposes.

In this research secondary data was collected from both published and unpublished data. Published data was collected from various publications of the governments including official web sites, various research reports prepared by research scholars and universities, books of various authors, magazines, and newspapers, various sources from university libraries, technical and trade journals, websites, and public records and other sources of published information.

The secondary research methods that were used in this study can be identified as follows:

Data available on the internet was extracted from government and defence forces websites. Most information was readily available on these websites and the internet. For secondary research some data was also collected from some government and nongovernment organisations since the information obtained from these agencies are authentic and trustworthy. The secondary data was also extracted from public libraries. Public libraries have copies of important research that were conducted earlier. They are a storehouse of important information and documents from which information can be extracted and libraries have a huge collection of government publications with market statistics, large collection of business directories and newsletters. Importance of collecting data from educational institutions for secondary research is often overlooked. But many researches are conducted in universities and academic institutes than any other fields. Even though the data collected by universities are mainly for primary research it was very useful as secondary data needed for this study. Commercial information sources such as newspapers, journals, magazines, radio and TV stations were also great methods of obtaining data for secondary research. For this research commercial information sources provided first-hand information on statistics of COVID-19 in Sri Lanka, contributions made by the defence forces, impact COVID-19 has on the economy, political agendas, and opinions of various personalities and public.

In the second stage, five (05) higher rank officials representing the tri forces and the Ministry of Defence (MOD) were chosen for one-to-one discussions. They were chosen as per the ranks and the responsibilities they hold as spokespersons for the respective institute they work for. These selected representatives had the fullest knowledge of the details of the incidents and information that was obtained from the secondary data and had the authority to clarify if the data was accurate. They were interviewed face to face at a location of their convenience and some were interviewed over the telephone. They elaborated on the various findings obtained from the secondary data and provided a wider understanding to the researcher. All these representatives have first-hand experienced the COVID-19 battle Sri Lanka went through and are the front liners and the strategic decision makers during the 
successful journey, and thus shared their experiences with the researcher fondly.

This qualitative study was conducted as a content analysis and the purpose of this content analysis was to organize and elicit meaning from the data collected and to draw realistic conclusions from it. "The researcher must choose whether the analysis should be of a broad surface structure or of a deep structure" (Berg, 2001). In a review of the literature, different opinions on the use of concepts, procedures and interpretation in content analysis are presented. There are four main stages identified but each stage must be performed several times to maintain the quality and trustworthiness of the analysis (Burnard, 1991).

\section{Trustworthiness}

Trustworthiness or rigor of a study refers to the degree of confidence in data, interpretation, and methods used to ensure the quality of a study (Polit \& Beck, 2014). The secondary data were all obtained by the government official websites which include the defence.lk and respective web sites of the tri forces. These websites contain only the reliable and accurate information. The researcher managed to ensure the trustworthiness of the information during the personal discussions and phone conversations held with respective tri forces members of authority.

\section{Reflexivity}

"A researcher's background and position will affect what they choose to investigate, the angle of investigation, the methods judged most adequate for this purpose, the findings considered most appropriate, and the communication of conclusions" (Malterud,
2001). According to Dowling (2006), reflexivity is the research process where the researcher reflects upon various theoretical assumptions and perspectives. During the research process, one may find themselves ruminating on the ways in which their own aspirations, characters, values, philosophies, experiences, belief systems, political commitments, and social identities have shaped the research. Reay (2007) argues that reflexivity is "about giving as full and honest an account of the research process as possible, in particular explicating the position of the researcher in relation to the research."

The most important lesson obtained from this research is that the research has both its power and limitation for social change and development. This research emphasises the importance in conveying ideas from those who have direct experiences of battling against COVID-19 to those who are assisting from outside. Many times, during the data collection the researcher realised the impact the defence forces have created in protecting the country from this deadly virus while putting their own safety at stake. Researcher has all but positive thoughts to support their efforts which will indeed create a change if utilized accordingly by policymakers and development implementers.

\section{Key Findings}

\section{Statistics}

To fulfil the first objective of the research and to analyse the effects created by COVID19 on Sri Lanka secondary data was analysed. The important statistics of Sri Lanka during the COVID-19 pandemic is identified as of 01st of December 2020 and summarised below:

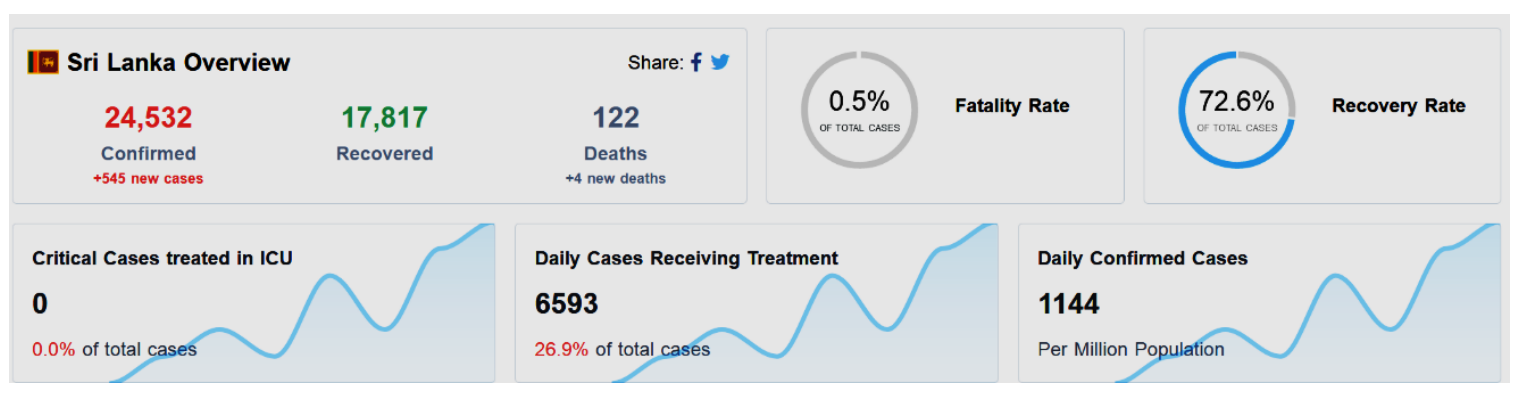

Figure 2: An Overview of the COVID-19 statistics of Sri Lanka on 01/12/2020

(Coronatracker.com, 2020) 
As seen in figure 2 the fatality rate of COVID-19 patients is $0.5 \%$ with a recorded $72.6 \%$ recovery rate. Main reason for these excellent results can be interpreted as the discipline conducted at the QCs and the efficient and effective service extended by the defence forces.

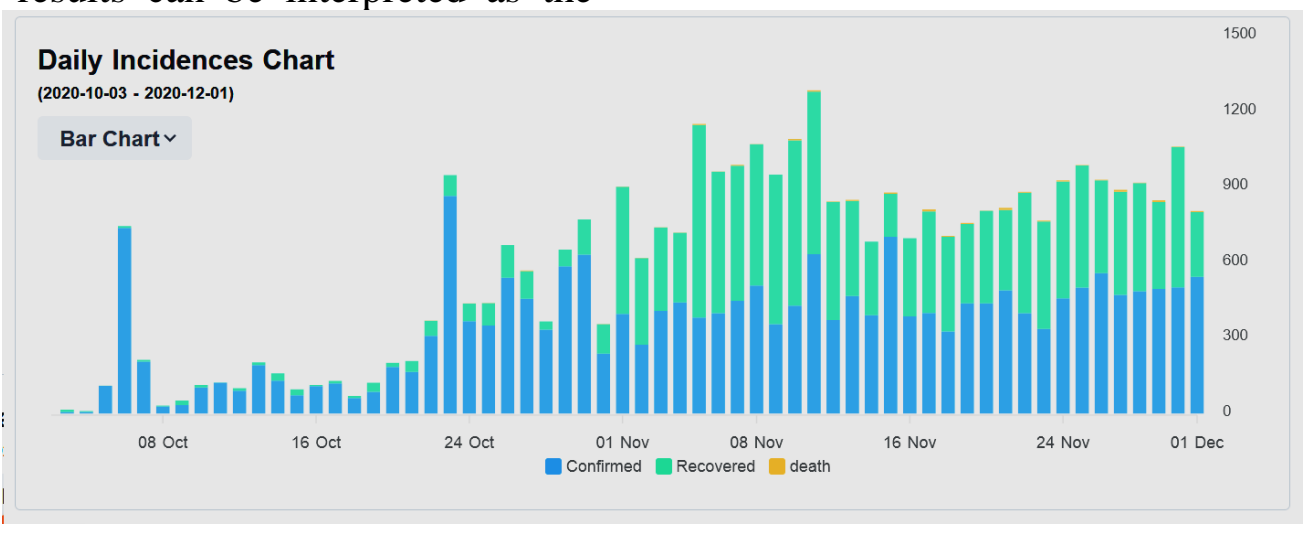

Figure 3: Daily incidences chart (Coronatracker.com, 2020)

When figure 3 is compared with fig 4 the increase in the number of infected patients Total Coronavirus Cases in Sri Lanka

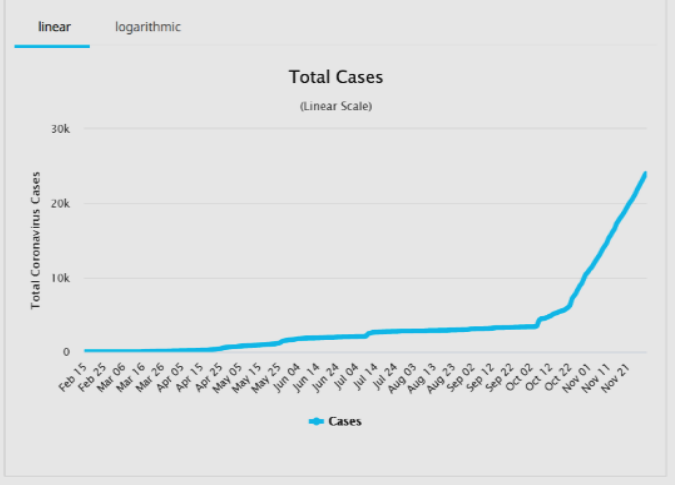

Figure 4: Total Coronavirus positive cases in Sri Lanka (Worldometer.com, 2020)

Figure 5 provides a snap shot of the active COVID-19 cases in Sri Lanka over the past 6 can be compared along with identification of the clusters that were formed.

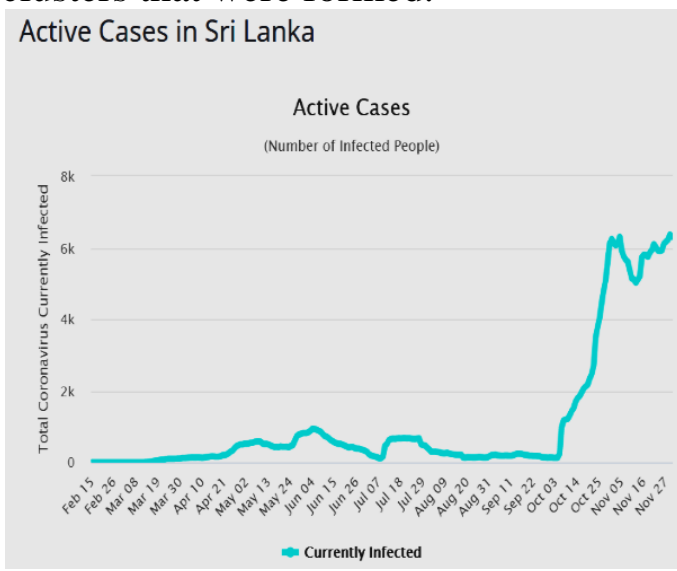

Figure 5: Active COVID-19 patients in Sri Lanka (Health.gov.lk, 2020)

months. Apart from the identified clusters the active cases seems to be declining over the months.

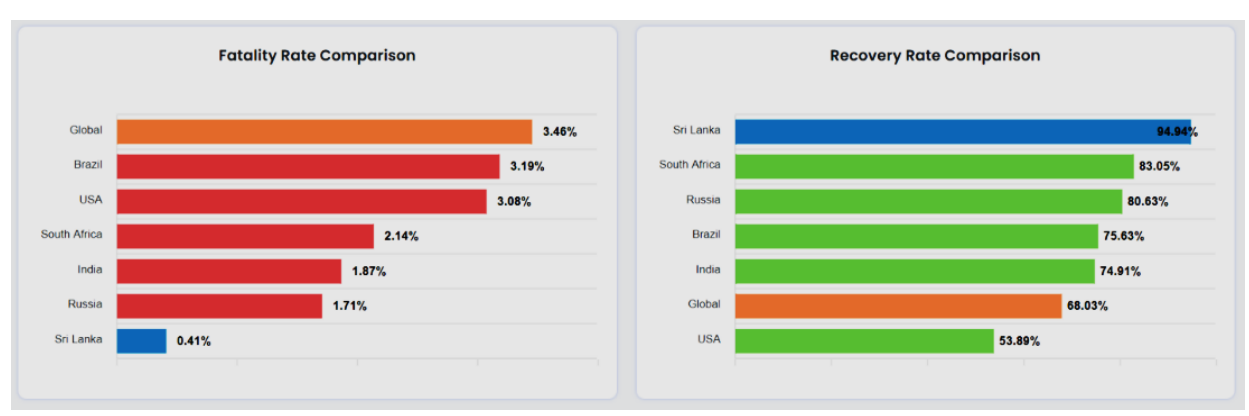

Figure 6: Fatality rate and Recovery rate comparison of Sri Lanka vs other countries (Health.gov.lk, 2020)

Comparison of COVID-19 with SARS and MERS

The research findings have identified that when compared, current COVID-19 outbreak is seen as both similar and different to the prior severe acute respiratory syndrome (SARS) 2002 and Middle East respiratory syndrome (MERS) 2012 
outbreaks. SARS was initiated at Guangdong Province, China. MERS was found in Saudi Arabia. Symptoms of the 3 viral infections start with fever and cough, which frequently lead to lower respiratory tract disease with poor clinical outcomes associated with older age and underlying health conditions. Confirmation of infection requires nucleic acid testing of respiratory tract samples (eg, throat swabs), but clinical diagnosis may be made based on symptoms, exposures, and chest imaging. Supportive care for patients is typically the standard protocol because no specific effective antiviral therapies have been identified. (McGoogan et.al, 2020)

WHO stated that the SARS outbreak reported a total of 8096 SARS cases and 774 deaths across 29 countries. MERS confirmed cases add up to a total of 2494 with 858 deaths across 27 countries (WHO, 2020). COVID19 has claimed more deaths due to the large number of cases. The total number of COVID-19 cases is higher due to difficulties in identifying and counting mild and asymptomatic cases. Furthermore, the stillinsufficient testing capacity for COVID-19 in the world means that many suspected and clinically diagnosed cases are not yet counted in the denominator (Battegay et.al, 2020).

Most secondary transmission of SARS and MERS occurred in the hospital setting while COVID-19 spread and transmission is occurring among close contacts. More research is needed in this area for more elaborated analysis to be done.

\section{Defence Forces of Sri Lanka}

Taking up the national responsibility of assisting the battle against COVID-19, Army, Navy and SLAF played a prominent role, together with stakeholders in the Ministry of Health (MOH), MOD, Office of the Western Province Governor, Ministry of Foreign Relations, Sri Lanka Aviation and Airport Authority, Department of Immigration and Emigration, SLP, Sri Lanka Transport Board and other relevant agencies across the country. Analysis of the secondary data proved that all three Defence Forces contributed to this immense task of fighting the COVID-19 in their own respective aptitudes.
"May it be the ground, air or sea, the presence of medical services is a morale booster for the troops engaged in battle and, military medical personnel are the first respondents not only in the battle but in any sort of humanitarian assistance and disaster relief operations conducted locally or overseas" stated the Defence Secretary Gen. (Retd) Kamal Gunaratne (Defence.lk, 14 March 2020).

\section{Contribution from the Sri Lanka Army}

The National Operation Centre for Prevention of COVID-19 (NOCPCO) was established with the objective of centralizing, expediting and implementing all necessary preventive and containing measures against the transmission of COVID - 19 pandemic and was headed by General Shavendra Silva, Chief of Defence Staff and Commander of the Army. (Army.lk, 15 March 2020)

As an emergency measure, Army as per the direction of the health authorities improvised all holiday homes at Diyatalawa to be QCs for returnees of various countries. Those holiday homes at Diyatalawa are equipped with all facilities and amenities. Army improvised five more buildings, situated in Wanni Echchankulam and Vavuniya to become functional as another Quarantine Centre. (Army.lk, 16 March 2020)

On March 26th when it was found that a COVID-19 confirmed patient had got in contact with 26 individuals in Ataluwagama, Bandaragama areas, immediate measures were adopted by Army in cooperation with medical authorities to isolate all of them in one improvised Quarantine Centre. (Army.lk, 26 March 2020)

Another issue arose in the Free Trade Zone (FTZ) areas in Wathupitiwela and Katunayake where employees, mostly females, remained stranded either in their boarding places or residential quarters, being unable to move out. Army troops with the coordination of respective employers transported a total of 5180 employees to their nearest destinations on the 27 of March. (Army.lk, 2020) 
All tri forces facilitated for over 500 quarantined individuals to travel home after completion of their quarantine process. Special instructions were issued to them for self-quarantine inside their own homes for another 14 days. Army also assisted the SLP to strictly impose Curfew hours and take the violators into custody to protect the people. (Army.lk, 2020)

Jaffna and Kundasale QC were also operated under Army. A person coming from a religious conference in India was taken to Punani QC who was suspected to have been in contact with 144 individuals. Akurana and Ataluwagama areas were kept in isolation under the purview of Army and 45 people who were suspected of being in contact with a COVID-19 patient from Maharagama were sent to Punani QC. Another group of 34 individuals who had contacts with a COVID19 positive person from Ratmalana and 21 people from Orugodawatte were admitted to the Punani QC. In addition, people from Matugama, Akuressa, Karapitiya, Piliyandala and Mahiyanganaya were despatched to the QC at Punani by Army. (Army.lk, 25 March 2020)

With the intention of creating a mental balance and well-being of the people who were confined to flats in Colombo during curfew hours, tri services and SLP organised staging of musical entertainment sessions during day time in selected areas. Army beat groups performed at Havelock city and Rajagiriya Housing complex. (Army.lk, 2020)

Army made a record when Corps of Engineer Services (CES) troops of Army improvised the former Voice of America building complex at Iranawila, Chilaw to be an isolation hospital and vested it with state authorities. This isolation hospital is equipped with 40 beds and has the capability to treat COVID-19 patients with the robotic technology and auto pilot vehicles. This is for the safety of medical staff working in the hospital and the patients are confined to separate cubicles during therapeutic process. Hemas Pvt Ltd and Atlas Company sponsored for these robots. Troops of the 1 CES under the supervision of Lieutenant Colonel Asiri Muhandiramge, completed the task of improvising and preparing the entire building to suit the emergency purpose within the time of two weeks. The complex is equipped with sanitary and cooking facilities, rest rooms, pantries, kitchen, along with a security system. (Army.lk, 27 March 2020)

20 Army riders of Army were put together for a Quick Reaction Team (QRT) to carry out random temperature checks on people who arrive in Colombo on essential services. The idea is to support the ongoing preventive mechanism of the government against COVID-19 in Colombo district. If a person is diagnosed with abnormal temperature and is unaware of their infection condition, such persons will be immediately sent to the respective hospitals for necessary onward arrangements. This ongoing project is facilitated by the Directorate of Army Operations. Army encourages the public to cooperate with the QRT members who would conduct such temperature checks for your own safety. (Army.lk, 2020)

When a COVID-19 positive detainee from the Welikada Prisons was identified as a returnee from Kandakadu Rehabilitation Centre, all prison detainees and prison staff were subjected to over 700 PCR tests. Under the Ministry of Justice two Rehabilitation Centres for Drug Prevention, Treatment and Rehabilitation are run at Kandakadu and Senapura areas in the Polonnaruwa district. Army converted the Kandakadu Quarantine Centre in to a field hospital where 500 COVID-19 infected persons can be treated (Army.lk, 2020).

In order to meet with the requirements at this critical juncture, QCs operate in Pompemadu, Punani, Kandakadu, Panichchankerni, Sri Lanka National Guard camp at Meeyankulam, Borawewa, Galkanda, Kahagolla, Army Base Hospital Diyatalawa, Gemunu Watch camp at Diyatalawa, Damminna and Rantembe under the purview of Army. These QCs are equipped with hand sanitizes, WiFi facilities, TVs, water boilers, fans, washing machines, towel racks, fridges, newspapers, special cooking arrangements for kids and pregnant women. Meals cooked by Army chefs and cooks are closely prepared, tested and tasted 
by Public Health Inspectors (PHIs) and nutritionists of the Army before they are served to the transients in those Centres (Army.lk, 2020).

Presidential Task Force (PTF) was appointed by $\mathrm{HE}$ the President in order to tackle health security at camps of the tri forces. PTF is responsible for preparing, implementing and monitoring an effective mechanism under the guidance of the Secretary of Defence and Commanders of Tri-Forces and would identify measures that need to be taken to ensure health security at military camps in view of the spreading epidemic (Army.lk, 2020).

Transport facilities of round trips, coordinated by tri services were made available to over 645,000 senior citizens who were supposed to collect their pensions (Army.lk, 2020).

\section{Contribution from the Sri Lanka Navy}

When the COVID-19 outbreak turned in to a pandemic across the world, Navy came aboard immediately to support the national responsibility by setting up a quarantine centre at the Boossa naval premises by 16th March 2020. The intention was to accommodate the passengers arriving from affected countries.

Navy personnel of the Welisara Navy camp participated in the isolation and quarantining work carried out in Suduwella, Ja-Ela area where drug addicts were identified and later found positive for COVID-19 and confined to QC. As a result of this, Welisara Navy camp-based 30 sailors were confirmed infected of COVID-19. Commander of the Navy had to isolate the entire camp premises with immediate effect (Navy.lk, 2020).

In order to control the spread of COVID-19 in the country Navy worked towards increasing facilities of the healthcare workers who have been doing a praiseworthy job even risking their own lives. Navy took over the task of improving facilities of the Dr. Neville Fernando teaching hospital to treat COVID-19 patients in a safe and effective manner. As a result, from 15th April 2020, Neville Fernando teaching hospital was declared as a hospital to treat suspected COVID-19 pregnant mothers (Navy.lk, 2020).

At the Neville Fernando Teaching Hospital, "using naval technology; construction of a building for patient admission and external sample testing, installing a camera system to treat patients while maintaining social distance, donation of a remote-controlled smart appliance called 'Medi Mate' to treat patent, installation of a disinfection chamber, construction of a high temperature chamber for sterilization of equipment and clothing used to treat patients infected with the virus, establishment of an infrared system in two premises of the hospital for sterilizing the areas travelled by patients and developing an electronic monitoring system for hospital elevators were successfully set up and installed" by Navy (Navy.lk, 2020).

On the 13 March 2020, Navy joined hands with Suwaseriya Ambulance Service, Firefighting Unit of Colombo harbour, Harbour Health Service and medical officers from National Quarantine Unit "conducted a drill at the harbour on to rehearse standard operational procedure that could be adopted in the event of transferring a suspected COVID-19 contracted patient from a ship to the relevant hospital ashore and quarantining a particular area on the land" (Navy.lk, 2020).

On 18 June 2020 an isolation ward complex at the Northern Command Naval Hospital premises for the treatment of COVID-19 patients were declared open along with a shipwright workshop operating with the latest technology. This isolation ward complex was completed within a short period of one month, in accordance with the COVID-19 standard guidelines and the ward complex provides residential care to 12 patients at a time (Navy.lk, 2020).

Navy music groups would conduct musical concerts in the best interests of the people at the premises of various housing flats. This was done keeping necessary social distancing and health guidelines which were necessary for people to safely enjoy those musical shows (Navy.lk, 2020). 
Naval troops of Navy completely disinfected the Colombo National Hospital premises and other public places of interest (Navy.lk, 2020).

The Navy Research and Development Unit (R \& DU) designed a remote-controlled smart appliance called 'Medi Mate' which allows healthcare professionals to maintain distance from patients during testing and treatment. Medi Mate is wheeled and remotecontrolled which then allows medical staff to communicate with patients, transport medicine and meals, and spray sanitizing liquid through its' automated nozzle. R \& DU of Navy also developed a disinfection chamber and variants with added features that were placed in medical institutes such as Kalubowila teaching hospital, Neville Fernando teaching Hospital and KDU hospital (Vega.lk, 08 April 2020).

\section{Contribution from the Sri Lanka Air Force}

SLAF started their first QC in Vanni which can accommodate over 200 residents. As per the guidance of Directorate of Health Services QCs were established in Palaly, Iranamadu and Mullaitivu. These Centres including the Vanni QC are manned by Medical professionals of the SLAF and $\mathrm{MOH}$. These centres were established with the aim of assisting the government's efforts in combating the COVID-19 (SLAF.lk, 20 March 2020).

SLAF commenced "renovation of wards 11 and 12 at the National Hospital for Respiratory Diseases at Welisara. An Engineering Team consisting of 5 Officers and 76 airmen from the Civil Engineering Wing at SLAF Base were deployed at the Welisara Hospital to carry out the renovation which was done within a very short period". These wards used as a QCs for those suspected to have been effected by COVID19 are manned by SLAF Medical personnel. (SLAF.lk 24 March 2020)

SLAF technical team from the "Electronics and Telecommunication Engineering ( $\mathrm{E} \&$ TE) Wing at SLAF Base Ratmalana, carried out the installation of Public Addressing Speaker Systems and Wi-Fi connected CCTV Camera Systems for 4 Wards at the
Mulleriyawa General Hospital. The installation was carried out by the Technical Team led by the Commanding Officer of the E \& TE Wing at Ratmalana, Group Captain Aruna Jayathilaka and was completed within 24 hours. Personnel from the SLAF Chemical Biological Radiological Nuclear and Explosive (CBRNE) Wing of the SLAF were also involved in order to ensure that the technicians were properly equipped in protective clothing while carrying out the installation. The CBRNE team also ensured that the technicians were properly disinfected after the installation. This enabled the health care professionals of the hospital to address and monitor patients infected by COVID-19" from a safer distance. (SLAF.lk 09 April 2020).

A team of civil engineering personnel from the Civil Engineering Wing (CEW) at SLAF Base Katunayake modified Ward No 1 of the Homagama General Hospital so it can be used to treat COVID-19 patients. A SLAF team of engineering personnel comprising of an Officer and 10 Airmen completed the modification of the ward within 3 days. The well-wishers and residents of Homagama area funded this project while SLAF provided the required manpower and engineering expertise. (SLAF.lk, 11 March 2020)

Another SLAF team of civil engineering personnel from SLAF Station Palavi renovated a ward at the District General Hospital-Chilaw, so that it can be used to treat COVID-19 patients. SLAF team of engineering personnel comprising of an Officer and 24 Airmen completed the renovation of the ward within 5 days. The District General Hospital provided funding for the project while the SLAF provided the required manpower and engineering expertise. (SLAF.lk, 20 April 2020)

With the global situation due to COVID-19 a threat of illegal migrants attempting to enter Sri Lanka by sea was identified. Therefore, SLAF conducted daily Aerial Surveillance Operations in support of the SL Navy's efforts of blocking illegal entry in to the island. SLAF aircraft from the No 8 Light Transport Squadron at Ratmalana and from the No 3 Maritime Squadron at SLAF 
Academy China Bay are being deployed to conduct this Aerial Surveillance. The aircraft conduct their surveillance operations along the International Maritime Boundary Line from Mannar up to Point Pedro. The main purpose is to observe and monitor sea vessels trying to breach the countries International Maritime Boundary Line. In addition to the above operations the SLAF conducts routine surveillance operations covering the entire island. The operations are done by dividing the island in to 8 main sectors. The SLAF utilizes Y-12 aircraft and Bell 212 helicopters from the No 3 and 8 Squadrons and the No 7 Helicopter Squadron (SLAF.lk, 15 April 2020)

SLAF developed a disinfection system to be implemented at the Bandaranayake International Airport which could be used for all passengers arriving by air. The Aeronautical Engineering Support Wing at SLAF Base Ratmalana developed, fabricated and installed a 'Passenger Disinfection Chamber' at the Arrivals Terminal of the Bandaranayake International Airport. "This newly developed Passenger Disinfection Chamber comprises of three main sections. The first section aims at disinfecting the upper back and head area. The second section targets the mid body section above the knee while the final section targets the lower body, legs and feet. In addition to spraying disinfecting liquid the spraying system consisting of specially designed nozzles atomizes the air and disinfectant liquid thereby creating a thick mist within the tunnel which, is intended to penetrate clothing in such a way that will ensure that any contaminants within cloths will also be cleaned. Further, all contaminated liquid from the tunnel is collected in a separate tank which will be properly disposed by SLAF CBRNE Personnel" (SLAF.lk, 27 April 2020).

\section{Conclusion and Implications}

According to the Brand Finance Sri Lanka (Gunawardena, 2020), Sri Lankan Brands Estimated to Drop 9.5\% in value following the impact of COVID-19 equating to Rs. 57.4 billion. This is believed to be the worst hit in the industries such as airlines, hotels, retail and automation. Everywhere around the world people are focused with finding health care strategies for minimising the impact of the new coronavirus COVID19 on the community. This virus has become a threat to the public health and seems to spread easily among people. The objectives of this research study was to identify the key contributions made by the Defence Forces of Sri Lanka during the battle against COVID19 pandemic attack, how that benefitted in uplifting the Nations branding, understand the effects created by COVID-19 on Sri Lanka and provide guidance for Sri Lankans with ways to continue life amidst COVID19.

The study was done using secondary data that was obtained from publications of the governments including official web sites, various research reports, books, magazines, newspapers, sources from university libraries, technical and trade journals. After analysing the data, it is evident that compared with many countries in the world, Sri Lanka is very successful in the fight against Covid19. Only 23,384 infected patients with 122 deaths in a population of over 21 million are figures to celebrate for.

The important statistics of the Sri Lanka's COVID-19 journey contributed to identifying the effect Covid-19 had on Sri Lanka. A Conceptual Framework was developed by the author in order to identify the contribution of the defence forces in the battle against COVID-19. This conceptual framework is the ideal fit for this qualitative study with content analysis as the main elements analysed were of Direction and Guidance, Supervision and Planning, Coordination and Control, and, Communications of the defence forces.

One of the main reasons behind Sri Lanka's success can be seen as how the country reacted rapidly to early warnings of the virus issued by the Chinese and WHO authorities. Many other countries in the west carried on a normal routine unconcerned and thinking it was only an issue in China. In spite of their limited resources, Sri Lankan government rapidly prepared the state funded health service responding with remarkable efficiency and the tri forces security being arranged with incredible speed. Pandemics 
tend to drive people apart rather than bring them together, but it can serve "to provide collective linkages between national selfinterest and international good" (Wang 2020). The contribution made from the defence forces towards battling COVID-19 is immeasurable and the key findings of the study had identified the various steps and projects separately.

The following reasons could be identified as the main strategies behind the success of Sri Lanka's fight against COVID-19.

\section{The lockdown was rapid and effective.}

On 14 March, the Sri Lankan government declared 16 March 2020, as a national public holiday to contain the coronavirus spreading in the country and closed all borders to foreign travellers and made people coming home quarantine for 14 days. Then full lockdown measures were introduced with imposing island-wide curfew. As per international guidelines only grocery stores, pharmacies, hospitals and gas stations could stay open, inter district travel was restricted, and social interaction was limited to within households. These lockdown rules were vital as they "suppressed the spread of the virus early and bought precious time that other countries wasted" (Pyzik, 2020).

\section{The Defence Forces joined in the battle} against COVID-19.

The tri forces lead by the MOD rapidly established QCs around the country. Their effort was highly efficient and the end result was of excellent quality. By 23rd of March, 45 QCs were built in the country by the Army and their mission continues. The unoccupied hotels offered by the private sector were enabled by the Army to facilitate people being quarantined. The defence forces renovated hospitals, innovated new technology and assisted the SLP with peacekeeping and law enforcement during the battle against COVID-19.

Outstanding contribution was made by the health Sector.

Sri Lankan government reacted quickly and adopted the WHO guidelines as soon as the rapidly escalating threat was made aware of. "Sri Lanka's state-funded universal health care service possessed considerable but unheralded expertise in managing deadly diseases, having eliminated malaria and polio, grappled successfully with AIDS, SARS, H1N1, Chikungunya and MERS and was substantially containing Dengue. In 2005, it avoided the much-anticipated epidemics following the Indian Ocean tsunami”. $\mathrm{MOH}$ instructed the Quarantine Unit at the Bandaranaike International Airport, Colombo, to screen passengers for suspicious symptoms and they warned that infants, children, pregnant women, the elderly and people who suffer from chronic diseases, among other issues, should avoid visiting crowded places. (Adaderana, 2020)

The rules were communicated efficiently and accurately.

All mass media, print media and web-based media worked in alliance when communicating important information to the public. The head of NOCPCO General Shavendra Silva, and Defence Secretary Gen. (Retd) Kamal Gunaratne along with the (former) Director General of health Dr. Anil Jasinghe and media spokesperson of COVID-19 DIG Ajith Rohana constantly held media briefings and updated the situation of the country. They not only clarified any doubts arose in the minds of the people but also tried to identify any issues and concerns people had and found answers to them efficiently. The consistent messaging about prioritizing health and frequent communication and daily media conferences facilitated by the Sri Lankan government ensured that all citizensincluding children-helped to contribute to win this battle.

Government took care of the needs of the people.

On 23rd of March, Sri Lankan President HE Gotabaya Rajapaksa introduced a relief fund called 'COVID-19 Healthcare and Social Security Fund' to combat COVID-19. The President himself contributed a sum of Rupes 100 million from the President Fund and he revealed that general public can delay the payments of the monthly electricity and water bills. With the assistance of the tri forces the government arranged home delivery of the essential goods to curb the coronavirus pandemic and also to control the crowd. 
The country started boosting its testing capacity.

Following the WHO advice around mass testing and robust contact-tracing, the SL government initiated testing on all returnees from other countries, people who are suspected of being in contact with an infected person as well as random sample testing.

Geography of the island played to the advantage of Sri Lanka.

Being an island has greatly helped Sri Lanka's pandemic response. This gave the government more control over who can enter to the country compared to countries with large land borders.

Sri Lanka has brought hope for the rest of the world and teaches a lesson that even the most severe situations can be turned around. In the COVID-19 era, a nation's ability to project positive influence and manage its nation brand ultimately hinges on how it has responded to the crisis. The Sri Lankan government's response to the COVID-19 pandemic and the high level of collective support from the Defence forces and the Health sector needs praise and appreciation. Although one might think that it is easy to get things done from military personnel as following orders is part of their job, it is actually not simple to get this kind of passion, commitment, interest, and an individual sense of duty. The correct guidance from the President, Defence Secretary and the three Commanders of the tri forces was the key to this success. All the countries around the world can learn from Sri Lanka's response to COVID-19 and start implementing prevention and control strategies immediately as health of each citizen is at risk. "Considering that each community is unique, assessment should be done of the possible benefits and negative consequences of each strategy adopted. In addition, countries should work on enhancing their systems and personnel in order to be more prepared for future outbreaks and reduce consequences when they strike" (Al Takarli, 2020).

As mentioned in the conceptual framework, the transformational qualities of the leaders of the defence forces contributed towards the success during COVID-19. The subordinates need to be motivated in order for them to offer their full cooperation to assist in the nation's battle against COVID-19. Therefore, the defence forces must invest in an effective system to build a succession of leadership which is sustainable.

Moynihan (2012) suggests that those in positions of authority must exhibit certain styles of leadership that are deemed effective in responding to disasters. The ability of a leader to motivate, communicate and articulate an organization's mission and to effectively lead during times of uncertainty is often cited as crucial components of effective emergency management (Stern, 2013). Such leaders can guide the behaviour of others by building coalitions of support, and cementing a clear vision and mission for an organization thus, creating a relationship between transformational leadership and organizational resiliency. In an emergency management context, a transformational leader may be perceived to effectively build a resilient organization, for instance, when he or she inspires and articulates a vision for handling future emergencies.

\section{Recommendations}

Fulfilling the final objective of the research and providing a guidance to continue life amidst COVID-19, a few recommendations can be made. Most important factor to be adopted is to control and suppress the spread of the virus. Along with that the health services should be strengthened and maintained with high standard. As the research firmly identified, obtaining the maximum cooperation from the defence forces is one of the most important factors for surviving COVID-19. Finally, every member of the community must support each other to stay safe and healthy.

Since there are no standard treatments for COVID-19, it is important to avoid infection or further spreading. Sanitising, washing hands regularly and wearing face masks to cover nose and mouth can be seen as preliminary precautions. People with a history of travel from epidemic areas in recent 14 days, body temperature monitor 
and quarantine for 2 weeks or more should be performed. If flu-like symptoms develop then the designated transportation should be taken to prevent unprotected exposure. Healthcare workers who come in contact with possible Covid-19 positive patients must use protective equipment. Corpses of patients should be burned or buried deep.

COVID-19 infection is an infectious viral disease with low to moderate mortality rate. To date, there is no standard treatment or cure found. Many countries are conducting experimental trials for a cure and a vaccine. Currently the best way to deal with COVID19 is to prevent a widespread outbreak and ensure infection is controlled. First-line healthcare providers should be highly aware of appropriate infection prevention measures for suspected patients. The defence forces should continue to provide their support and strength to control and fight off this deadly disease.

\section{Limitations and Future Research}

The COVID-19 global pandemic has affected every area of our lives, and has made larger effects in education, with higher education and research activities taking place in online form. Therefore, this research had to be limited to a qualitative study mainly undertaken with content analysis of secondary data. Even though a chosen faceto-face and telephone conversations took place, the research could have an additional value if a significant amount of primary data was included in the study. The information received from various secondary data sources were not precise to what the researcher needed and also were at times incomplete with full details required.

In spite of those limitations, the research has made some significant contributions to the understanding of the effects of COVID-19 for Sri Lanka and the contribution extended by the defence forces in the battle against COVID-19. The findings of the research have made recommendations of how to continue life amidst COVID-19.

This research provides a starting point for researchers to conduct formal and informal research on the impacts of the COVID-19 on
Sri Lanka and the contribution of the defence forces in this journey. Research is a crucial factor in the battle against COVID-19 as many scientific discoveries are required for survival with the virus. The world is witnessing many countries involved in various types of research on COVID-19. Such research findings are constantly influencing governmental policies and public opinions especially in terms of Nations branding. "International organizations, reputable scientific journals, and funding bodies have been calling educational researchers around the world to collaborate and cooperate in an open manner" (Chan, 2020). Therefore, this research paper will influence and inspire further research to be conducted in the areas of COVID-19 pandemic in Sri Lanka. One such topic for future research can be suggested as a comparison of the journey during COVID-19 of Sri Lanka with the aid of the Defence forces as opposed to any country that did not receive the assistance or contribution from their defence forces.

\section{References}

Al Takarli, N.S. (2020), China's Response to the COVID-19 Outbreak: A Model for Epidemic Preparedness and Management, Dubai Medical Journal, 3(1): 13-18.

Andrews, L., Higgins, A., Andrews, M. W. and Lalor, J.G. (2012), Classic Grounded Theory to Analyze Secondary Data: Reality and Reflections, The Grounded Theory Review International Journal, 11(1): 12-26.

Anholts, S. (2004), Nation-brands and the value of provenance, Destination branding Journal,26-31.

Anholt, S. (2007) Competitive identity: The new brand management for nations, cities, regions. Basingstoke, UK: Palgrave Macmillan.

Battegay, M., Kuehl, R., TschudinSutter, S., Hirsch, H.H., Widmer, A.F. and Neher, R.A. (2020), Novel coronavirus (2019-nCoV): estimating the case fatality rate: a word of 
caution, International Journal of Infectious Diseases, 97: 1-6.

Berg, B.L., (2001), Qualitative research methods for the social sciences, 4th Edition, California State University, Long Beach, Pearson.

Bharel, M ., (2020), Crisis standards of care planning guidance for the COVID-19 pandemic. Department of Public Health Official Reports, Massachusetts, Boston, MA.

Burnard, P., (1991), A method of analysing interview transcripts in qualitative research, Nurse Education Today, 11: 461 - 466.

Bradley, P., and Charbonneau, D. (2004). Transformational Leadership: Something New, something old.Military psychology. Canadian Military Journal, 1(1).

Chan, R.Y., (2020), Studying Coronavirus (COVID-19) and Global Higher Education: Evidence for Future Research and Practice, Indiana University Press, 6(1).

Daily News Paper, (2020), Covid-19 daily news reports, Official web site, www.dailynews.lk.

Derana News, (2020), Covid-19 news reports, Official web site of Ada Derana, www.adaderana.lk.

Dowling, G., (2006), How Good Corporate Reputations Create Corporate Value, Corporate Reputation Revision, 9: 134-143.

Economist (2020), The new coronavirus could have a lasting impact on global supply chains, The Economist Official web site, https://www.economist.com.

Elder, G.H., Wang, L., Spence, N.J., Adkins, D.E. and Brown, T.H. (2010), Pathways to the All-volunteer Military, Social Science Quarterly, 91: 455-75.

Epidemiology Unit Sri Lanka, (2020), Epidemiology Unit of Ministry of Health \& Indigenous Medical Services Official Website, https://www.epid.gov.lk.
Fan, Y. (2010). Branding the nation: Towards a better understanding. Place Branding and Public Diplomacy, 6(2), 97-108.

Financial Times News Paper, (2020), Daily reports on Covid-19, The Daily Financial Times official website, www.ft.lk.

Guardian, (2020), China's coronavirus lockdown strategy: brutal but effective, Official Website of The Guardian, https://www.theguardian.com

Gunewardene, R. (2020) Brand Finance Sri Lanka 100 2020, Brand Finance Lanka, https://www.brandirectory.com/rankin gs/sri-lanka.

Hamad, H., (2015), Transformational Leadership Theory: Why Military Leaders are More Charismatic and Transformational?, International Journal on Leadership, 3(1):1-8.

Health Promotion Bureau Sri Lanka, (2020), COVID-19 Situation Report, Official web site of Health Promotion Bureau (Sri https://hpb.health.gov.lk/covid19 2020.

Hiru News, (2020), Covid-19 daily news reports, Official web site, www.hirunews.lk.

Kerr, P. (2013). Diplomacy in a globalizing world: theories and practices. New York: Oxford University Press, USA. 354.

Lester, W. and Krejci, D. (2007), Business Not as usual: the national incident management system, federalism, and leadership, Public Administration Review, 67(1): 84-93.

Li, Q., Guan, X., and Wu, P.(2020), Early transmission dynamics in Wuhan China of novel coronavirus-infected pneumonia, The New England Journal of Medicine, 1(29).

Malterud, K. (2001), Qualitative research: Standards, challenges and guidelines, The Lancet, 358: 483-488.

Ministry of health, (2020), Daily COVID-19 Reports, Official Website, http://www.health.gov.lk. 
Moynihan, D.P. (2012), “A theory of cultureswitching: leadership and red tape during HurricaneKatrina",Public Administration, 90(4) :851-868.

Newsfirst News (2020), Covid-19 daily news reports, Official web site, www.newsfirst.lk.

Polit, D.F., and Beck, C.T. (2014), Essentials of nursing research: Appraising evidence for nursing practice 8th edition, Lippincott Williams \& Wilkins, Philadelphia, PA.

Pyzik, O., (2020), COVID-19 vaccine won't help if people don't trust it, UCL School of Pharmacy Website, https://www.ucl.ac.uk.

Reay, D., (2007), Unruly Places: Inner-city Comprehensives, Middle-class imaginaries and Working-class, The Geography of Education, 44(7): 11911203.

Srinivasan , M., (2020), COVID-19 | Sri Lankan military is helping the country fight the pandemic, The Hindu, 15 April 2020

Smith, E. (2008), Using Secondary Data in Educational and Social Research, New York, NY: McGraw-Hill Education.

Sunday Times News Paper, (2020), Covid 19 reports, Official website of The Sunday Times, www.sundaytimes.lk.

Sunday Observer News Paper, (2020), Govt mulls nation-branding initiative, Official website of The Sunday Observer, http://www.sundayobserver.lk

Thompson, (2020). What's behind South Korea's COVID-19 exceptionalism? TheAtlantic.https://www.theatlantic.co m/ideas/archive/2020/05/whats-southkoreas-secret/611215/.

Vega, (2020), Low-cost Medical Ventilator Manufactured by Vega Innovations to Support COVID-19 Outbreak, Official Website, www.vega.lk.

Wang, J. (2020), Public diplomacy in the age of pandemics, USC Center on Public Diplomacy.

https://www.uscpublicdiplomacy.org/ blog/public-diplomacy-age-pandemics
Warilow, S. (2012), The transformational leadership theory: The 4 key components in leading change and managing change, Journal of Global Responsibility, 6(1): 99-112.

Whitty, C., (2020), COVID-19:Chris Whitty gives an initial view of the pandemic, Gresham College Website, https://www.gresham.ac.uk.

Worldometer, (2020), Total coronavirus cases, Official Website, https://www.worldometers.info/corona virus/country/srilanka.

World Health Organization, (2020), Critical preparedness, readiness and response actions for COVID- 19, Official website of WHO, https://www.who.int/publicationsdetail/critical-preparedness-readinessand-response-actions-for-covid- 19 .

World Health Organisation, (2020), Coronavirus disease 2019 (COVID-19) Situation Report Sri Lanka, Official Website of WHO, https://www.who.int/srilanka/covid19.

$\mathrm{Wu}, \mathrm{Z}$. and McGoogan, J.M., (2020) Characteristics of and important lessons from the coronavirus disease 2019 (COVID-19), Reports from Chinese Center for Disease Control and Prevention, 323(13): 1239.

Zhong, R. and Mozur, P. (2020), To tame coronavirus, Mao-style social control blankets China. The New York Times, 2(15). 